\title{
Land Use Change Trajectories for Wetland Management (Mogi-Guaçu Floodplan River, Southern Brazil)
}

\author{
Angela Terumi Fushita1, José Eduardo dos Santos ${ }^{2}$ \\ ${ }^{1}$ Center for Engineering, Modeling and Applied Social Sciences, Universidade Federal do ABC (UFABC), Santo André, Brazil \\ ${ }^{2}$ Pos-Graduate Programme in Ecology and Natural Resources, Universidade Federal de São Carlos (UFSCar), São Carlos, Brazil \\ Email: angela.fushita@ufabc.edu.br,djes@ufscar.br
}

How to cite this paper: Fushita, A.T. and Santos, J.E. (2017) Land Use Change Trajectories for Wetland Management (Mogi-Guaçu Floodplan River, Southern Brazil). Journal of Geoscience and Environment Protection, 5, 62-76.

https://doi.org/10.4236/gep.2017.510006

Received: August 24, 2017

Accepted: October 16, 2017

Published: October 19, 2017

Copyright $\odot 2017$ by authors and Scientific Research Publishing Inc. This work is licensed under the Creative Commons Attribution International License (CC BY 4.0).

http://creativecommons.org/licenses/by/4.0/

\begin{abstract}
Natural and anthropogenic factors are responsible for changes in wetland function and structure. This research deals with the complexity of interactions among flood attributes, climatic data and land use trajectories to track the impact of land use changes for wetland management, over 30 years (19842014). This paper presents a multi-temporal analysis of a floodplain to know the inter-annual ecohydrological variability, including extraordinary events of floods and droughts, using indicators of hydrological regime. It also presents a quantitative description of the geospatial variability in the Mogi Guaçu wetland components to assess the changes in the conversion, replacement, of wetland landscapes by anthropic growth activities. Flood attributes and anthropogenic pressures have altered temporal habitat variability in changes on the river course, in sandbars extent, and oxbow lake genesis and extinction, with a decline in the biota dependent on these habitats. These results have significant implications of the quick expansion of anthropogenic activities and provide key information about the impact of land use changes on the wetland function and structure. It is an objective tool to help the environmental management of wetland areas.
\end{abstract}

\section{Keywords}

Flood Pulse, Anthropogenic Activities, Loss of Habitat Diversity, Remote Sensing

\section{Introduction}

The Ramsar Convention's definition of wetland is broad and, along with natural 
wetlands, encompasses human-made wetlands [1]. Wetlands cover about $4 \%$ $6 \%$ of the world's land surface and their degradation is a continuous and serious problem worldwide [2]. It is estimated that wetland areas have declined from $64 \%$ to $71 \%$ in the 20 th century [3].

Natural and anthropogenic factors, as well as their synergistic combinations are mainly responsible for changes in wetland functions and structures [4] [5] [6] [7].

Land use intensification is a major driver of naturalness and biodiversity loss, as well as reductions in local species diversity and biotic homogenization, which is a matter of great concern for conservation [1] [8]. Threats to wetlands also include agro-industrial expansion, deforestation, soil erosion, pollution, mining, inappropriate use of resources and large infrastructural projects such as reservoir construction for hydropower, river channeling, road constructions and navigation [9]. These anthropogenic pressures contribute to wetland transformations [10] and lead to land use changes.

Land use changes in wetlands have altered temporal habitat variability in geomorphic templates (i.e. changes on the river course, in sandbar extent formation, and oxbow lake genesis and extinction) [11], and have brought about a decline in the biota dependent on terrestrial and an aquatic transition wetland habitats (Fischer et al. 2015). Detecting land use changes is an important tool to identify geographical dynamics and their association with anthropogenic activities. Moreover, it has been studied through remote sensing, landscape metric and change detection methods [4] [7].

In tropical to subtropical regions, the predictability of flood pulse systems facilitates the evolutionary adaptation of organisms to spatiotemporal dynamics. The flood-pulsing systems in most of the South American wetlands oscillate between a terrestrial and an aquatic transition because precipitation regimes have marked rainy and dry seasons throughout the year. They provide a variety of ecosystem services, i.e. decomposition, regulating biogeochemical cycles, providing habitats, primary and secondary productivity and sustaining cultural practices [9].

Mogi-Guaçu wetland (Southern Brazil) may be considered a flood-pulsing system with significant hydrographic and physiographic modifications. The magnitude and intensity of flood pulse occurrence during the year did not reached the wetland full extent, resulting in the genesis and extinction of oxbow lakes at time intervals over the 30-year (1984-2014) [11].

This research deals with the complexity of interactions between flood attributes, climatic data, and different land use/cover, their temporal and spatial changes, over 30 years (1984-2014), to track the impact of land use/cover changes for improve wetland sustainable management.

\section{Material and Methods}

\subsection{Study Area}

The study was carried out in a wetland area located in a meander zone of the 
Mogi Guaçu River basin, subject to periodic flooding via overflow from the river channel [12], in the surrounding areas of the Jatai Ecological Station protected area (Figure 1).

The Mogi Guaçu River basin has three distinct geomorphological regions: the source area, which is characterized by steep slopes at a mean elevation of 1,650 $\mathrm{m}$, located in the Bom Repouso Municipality (Minas Gerais State) on the Cristalino Plateau; the middle stretch river, which is characterized by a geological fault occupied by a meander zone and located in the northeastern region of São Paulo State on the Central Plateau; and the downstream stretch, where the river runs without meanders until it joins the Pardo River in the Pontal Municipality (São Paulo State at an elevation of $490 \mathrm{~m}$ [13].

The wetland study area occupies an area of $176.27 \mathrm{~km}^{2}$. It generally features unconsolidated hydromorphic soils (certain reaches feature consolidated soils). The climate region (Köppen) is Aw type that characterizes a tropical climate with dry winters (May to October) and a rainy season (November to April). The minimum temperature is between $18.5^{\circ} \mathrm{C}$ to $19^{\circ} \mathrm{C}$; the maximum temperature is $23.5^{\circ} \mathrm{C}$ to $24^{\circ} \mathrm{C}$. The annual precipitation is 1100 to $1700 \mathrm{~mm}$. The primary economic activity in the Mogi Guaçu River basin is related to sugarcane and orange cultivation, forestry and pastures.

\subsection{Methodological Procedures}

The historical series of daily water level data is available at the São Paulo Basic Hydrologic Network [14] and was obtained from the São Carlos station (4C-007). The climate data for the wetland study area were obtained for the period from 1971 (January) to 2014 (December) through time series available at the National Institute of Meteorology [15]. Pearson correlation was performed using

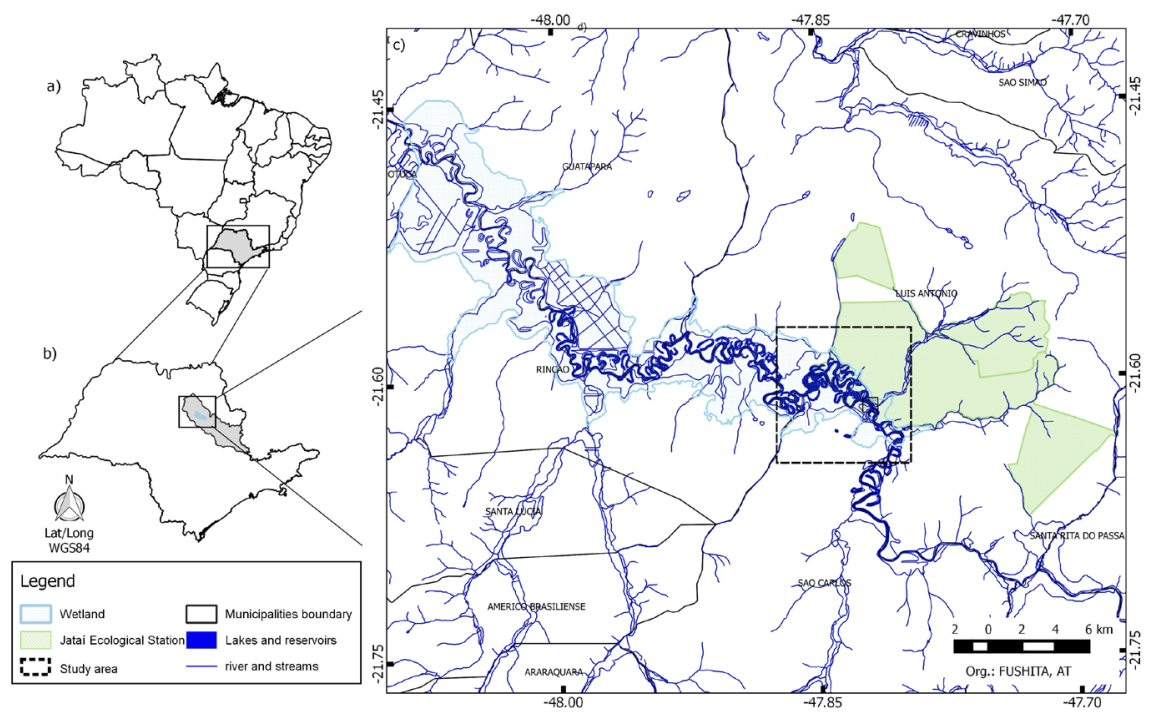

Figure 1. Location of the wetland study area in the Mogi Guaçu River basin (c), São Paulo State (b); Brazil (a). In detail: Wetland study area corresponding to a meander zone section of the Mogi Guaçu River and Jatai Ecological Station. 
the vegan package of $\mathrm{R}$ software [16] [17].

Hydrological data and flood attributes were processed according to [18] and [19] in order to establish the flood attribute: frequency (number of times that floods have occurred in a period of time), recurrence (statistical probability that a flood will occur within a period of time or number of occurrence by year), permanence (days/year that the water remains in a wetland), seasonality (frequency of the flood occurrences, permanence throughout the year), potamophase (time lapse in which bodies of water, i.e. wetlands and lakes are connected to waters of the river course), limnophase (period in which the river course remains isolated from the wetland) and FCQ-Fluvial Connectivity Quotient (relation between the number of days of floods and the number of dry days).

Wetland land use/cover dynamics were identified over the 30-year (1984-2014). The qualitative and quantitative land use/cover typologies were obtained through on-screen digitizing of Landsat-5 TM images (path 220, row 075; dated June 20, 1984; July 4, 1989; June 16, 1994; August 1, 1999; June 27, 2004; and August 12, 2009) and Landsat-8 OLI imagery (path 220, row 075; August 3, 2014) with multispectral composite of the near infrared, red and green bands using ArcGIS 10.2 software. All of the images were clear and nearly free of clouds. The classification accuracy to 2014 data was based on field data and determined using the Kappa $(\mathrm{k})$ index [20], and values were considered significant when $\mathrm{k} \geq 0.90$.

Through quantitative land use/cover dynamics, over the 30-year (1984-2014), a land use change matrix for each five-year period between 1984 and 2014 was carried out using the raster [21] and dismo [22] package of R software [17]. The conversion rates describe state transitions resulting from various types of landscape changes related to the number of structural features and the change trajectory during a period [23].

Based on land use change matrix, pointing out the main types of gains and losses in each land use/cover category, four conversion contribution rates were calculated: Conversion-in $\left(\mathrm{C}_{\text {in }}\right)$, Conversion-out $\left(\mathrm{C}_{\text {out }}\right)$, Retention rate $(\mathrm{R})$, and Area change rate (CR). The $\mathrm{C}_{\text {in }}$ is the ratio of the conversion area from other landscape elements to a specific landscape element to the total landscape conversion area; $\mathrm{C}_{\text {out }}$ is the ratio of the conversion area from a specific landscape element to another landscape; $(\mathrm{R})$ is the retention rate of landscape type between the comparison time periods and shows the stability of landscape type; and CR is the level of landscape change in response to the landscape tendency [4].

\section{Results and Discussion}

\subsection{Flood Attributes and Climate Data}

Many biogeochemical processes in wetlands are closely related to the alternation of drought and flood periods, i.e. the frequency, intensity, duration and seasonality of connectivity between the wetland and the fluvial course [18]. The geomorphological and hydrological conditions of the Mogi Guaçu wetland are re- 
lated to polymodal flood pulses that range from unpredictable to predictable and vary in amplitude, although they are always short lived [11] [12].

Studies in the Mogi Guaçu wetland have shown that the bankfull discharge or the flow rate, when the water level exactly fills the river channel, is $380 \mathrm{~m}^{3} / \mathrm{s}$ in the Mogi Guaçu River. Above $380 \mathrm{~m}^{3} / \mathrm{s}$, water overflows into the wetland. When the river reaches a flow rate of $752 \mathrm{~m}^{3} / \mathrm{s}$, the total wetland area is flooded [24].

The flood attributes and climatic data in the Mogi Guaçu wetland over a 43-year (1971-2014) was used to infer which pulse attributes (e.g. frequency, intensity, tension, regularity, amplitude, seasonality) produce changes in community integration, phenological characteristics or determined population growth and to obtain synthetic indicators of the relationships between plants and the environment in which they live [18].

The flood pulses occur in the rainy season from November to April of each year. Hydrological data from 1971 to 2014 concerning the Mogi Guaçu wetland indicate that the average recurrence of floods (typical alternation of flood and drought phases) was 3.23 times/year, permanency $=29.12$ days/year and FCQ $=$ 0.087. The low FCQ values over the 43-year period (1971-2014) were used to compare partial periods within a time series to look for changes in the communities as a consequence of anthropogenic modifications in the hydrological regime of rivers.

Higher values of flood attributes, mainly river flow (maximum and average), flood pulse (maximum and average), potamophase, frequency, permanency and FCQ were observed from 1980-1984, 1990-1994 and 1995-1999 over the 43-year period (1971-2014), corresponding to the El Niño Southern Oscillation (ENSO) strong influence, especially for the warm ENSO-phase that causes large-scale precipitation anomalies in the Southeast.

The ENSO influences water-level fluctuations and discharge in the catchments of many tropical rivers [25]. There are strong relationships between ENSO, as well as flood frequency and duration across a large number of river basins spread across the world and discuss ENSO's influence related to the number of floods per year and/or the duration time of the floods.

In the wetland study area over the 43-year (1971-2014), the warm ENSO-phase would be narrowly confined just in 14 years, previously reported by [26]-[31] with strong or very strong events which occurred from 1982-1983, 1997- 1998 and 2015-2016 [30].

Higher precipitation and river flood rates in the Mogi Guaçu wetland, with river flood values above $752 \mathrm{~m}^{3} / \mathrm{s}$, may be related to up to two years of a warm El Niño phase occurrence. However, there is little evidence showing decreased precipitation in wetland areas over the last decade, but temperatures (mean and maximum) have increased $1^{\circ} \mathrm{C}$ since 1971 . Although the precipitation is strongly correlated with the flow rates $(r=0.69, p=0.001)$, climate conditions are not a single factor to explain flood pulse magnitudes and flow rates.

Wetlands on sand soils recharge groundwater when flooded and are fed by 
groundwater in droughts, ensuring the flow river perennity. The water movement between the wetland and the ground may change according to hydrological conditions [32]. The environmental consequences of groundwater depletion go beyond reduced availability of freshwater and changes in aquifer recharge patterns (groundwater), but increase the extremes of floods and droughts [33].

The gradual increase in temperature and low precipitation rates over the last decade has changed the natural dynamic and the minimum groundwater reserve to vegetation absorption with a decrease in the flow river rate in the long-term. Hidrological periodicity of the river flow and flood pulse. Natural processes changed the timing and magnitude of soil moisture and groundwater deficits by up to several years and caused the amplification of rainfall declines to be greater than in normal dry years [34]. Moreover, anthropogenic modifications in ecosystems have accelerated these processes. Groundwater availability and land use changes are mainly driving forces that can affect hydrology.

Flow rates and flood pulse magnitudes observed since 2000 in the Mogi Guaçu wetland have not been sufficient to cover the entire wetland and have failed to reach $752 \mathrm{~m}^{3} / \mathrm{s}$. They have also resulted in fluvial geomorphological processes, such as the extinction and genesis of oxbow lakes and changes of the river course, all of which have been accelerated by anthropogenic activities [11].

\subsection{Land Use/Cover and Conversion Rate Trajectory}

Three primary land use classes were identified for the study area (Table 1), over 30 years (1984-2014): the aquatic (river channel and oxbow lakes); natural (sandbars, marsh, and terrestrial vegetation), and anthropogenic (agricultural and bare soil, forestry, mining, and urban area), with ground truthing in 2014. The results based on multi-temporal satellite imageries were illustrated in Figure.

Table 1. Area (\%) of land use/cover typologies in Mogi Guaçu wetland (Southern Brazil), for each five-year period between 1984 and 2014.

\begin{tabular}{ccccccccc}
\hline \multicolumn{2}{c}{ Land use/cover typologies } & \multicolumn{7}{c}{ Area (\%) } \\
\hline Primary class & Secondary class & 1984 & 1989 & 1994 & 1999 & 2004 & 2009 & 2014 \\
\hline \multirow{2}{*}{ Aquatic } & River & 4.64 & 4.11 & 4.19 & 4.28 & 4.37 & 4.39 & 3.10 \\
& Oxbow lake & 2.92 & 2.01 & 2.13 & 1.49 & 0.81 & 0.56 & 0.68 \\
& Sandbars & 0.40 & 0.53 & 0.43 & 0.51 & 0.55 & 0.19 & 0.98 \\
Natural & Marsh & 26.30 & 29.07 & 29.91 & 26.96 & 23.16 & 23.87 & 18.06 \\
& $\begin{array}{c}\text { Terrestrial } \\
\text { Vegetation }\end{array}$ & 44.67 & 40.18 & 37.88 & 42.53 & 44.62 & 45.55 & 43.75 \\
& $\begin{array}{c}\text { Agriculture and } \\
\text { exposure soil }\end{array}$ & 20.80 & 20.91 & 21.09 & 18.84 & 18.55 & 16.63 & 24.52 \\
& Urban area & 0.10 & 2.47 & 3.53 & 3.80 & 6.37 & 7.11 & 6.96 \\
& Mining & 0.18 & 0.72 & 0.82 & 1.60 & 1.57 & 1.70 & 1.94 \\
& & 100.00 & 100.00 & 100.00 & 100.00 & 100.00 & 100.00 & 100.00 \\
\hline
\end{tabular}


The four conversion rate values $\left(\mathrm{CR}, \mathrm{R}_{\mathrm{in}}\right.$, and $\mathrm{C}_{\text {out }}$ ) for the Mogi Guaçu wetland (Table 2) support to understand land use/cover trajectory and they summarized the land use change matrix for each five years, over the 30 -year period (1984-2014).

The natural land use/cover (sandbars, marsh, and terrestrial vegetation) was the prevalent land use, occupying above $63 \%$ of the total study area, and a range above $40 \%$ predominantly occupied by terrestrial vegetation land cover, over the 30-year period (Table 1 and Figure 2). Terrestrial vegetation land cover decreased in area from the 1980s to 1990s, with a subsequent recovery in the 2000s and 2010s (Table 1).

The changes in terrestrial vegetation area (Table 1), over the 30-year period, explain the high Retention Rate (R) values (79\% to $92 \%$ ), and the maintenance of this land cover area, over the 30-year period (Table 2). Furthermore, high $\mathrm{R}$

Table 2. Conversion contribution rate values: Landscape Total Conversion Rate (CR), Retention Rate (R), Contribution Rates of Conversion-in (Cin) and Conversion-out ( $\mathrm{C}_{\text {out }}$ ) for Mogi Guaçu wetland (Southern Brazil), over 30-year period (1984-2014).

\begin{tabular}{|c|c|c|c|c|c|c|c|}
\hline \multicolumn{2}{|l|}{ Years } & 1984-1989 & 1989-1994 & 1994-1999 & 1999-2004 & 2004-2009 & 2009-2014 \\
\hline \multicolumn{2}{|l|}{ CR } & 25.98 & 24.06 & 29.15 & 19.43 & 15.85 & 35.18 \\
\hline \multirow{3}{*}{ Oxbow lake } & $\mathrm{R}$ & 0.33 & 0.29 & 0.19 & 0.34 & 0.46 & 0.01 \\
\hline & Cin & 0.04 & 0.06 & 0.04 & 0.02 & 0.01 & 0.02 \\
\hline & Cout & 0.08 & 0.06 & 0.06 & 0.05 & 0.03 & 0.02 \\
\hline \multirow{3}{*}{ Sandbars } & $\mathrm{R}$ & 0.32 & 0.21 & 0.2 & 0 & 0.18 & 0.16 \\
\hline & Cin & 0.02 & 0.01 & 0.01 & 0.03 & 0.01 & 0.03 \\
\hline & Cout & 0.01 & 0.02 & 0.01 & 0.01 & 0.03 & 0.01 \\
\hline \multirow{3}{*}{ Marsh } & $\mathrm{R}$ & 0.76 & 0.74 & 0.62 & 0.72 & 0.8 & 0.5 \\
\hline & Cin & 0.35 & 0.35 & 0.29 & 0.19 & 0.34 & 0.22 \\
\hline & Cout & 0.25 & 0.02 & 0.39 & 0.39 & 0.3 & 0.42 \\
\hline \multirow{3}{*}{$\begin{array}{l}\text { Terrestrial } \\
\text { vegetation }\end{array}$} & $\mathrm{R}$ & 0.79 & 0.78 & 0.84 & 0.92 & 0.89 & 0.78 \\
\hline & Cin & 0.19 & 0.26 & 0.36 & 0.28 & 0.38 & 0.29 \\
\hline & Cout & 0.36 & 0.36 & 0.2 & 0.18 & 0.32 & 0.36 \\
\hline \multirow{3}{*}{ Agriculture } & $\mathrm{R}$ & 0.72 & 0.83 & 0.71 & 0.78 & 0.81 & 0.94 \\
\hline & Cin & 0.23 & 0.15 & 0.13 & 0.19 & 0.1 & 0.31 \\
\hline & Cout & 0.23 & 0.15 & 0.21 & 0.21 & 0.22 & 0.04 \\
\hline \multirow{3}{*}{ Urban } & $\mathrm{R}$ & 1 & 0.87 & 0.78 & 0.73 & 0.96 & 0.96 \\
\hline & Cin & 0.09 & 0.06 & 0.04 & 0.18 & 0.06 & 0 \\
\hline & Cout & 0 & 0.01 & 0.03 & 0.05 & 0.02 & 0.01 \\
\hline \multirow{3}{*}{ Mining } & $\mathrm{R}$ & 0.21 & 0.81 & 0.71 & 0.44 & 0.81 & 0.65 \\
\hline & Cin & 0.03 & 0.01 & 0.03 & 0.04 & 0.03 & 0.03 \\
\hline & $\mathrm{C}_{\text {out }}$ & 0.01 & 0.01 & 0.01 & 0.05 & 0.02 & 0.02 \\
\hline \multirow{3}{*}{ River } & $\mathrm{R}$ & 0.57 & 0.53 & 0.38 & 0.75 & 0.73 & 0.18 \\
\hline & Cin & 0.06 & 0.08 & 0.09 & 0.06 & 0.08 & 0.08 \\
\hline & Cout & 0.08 & 0.08 & 0.09 & 0.06 & 0.07 & 0.13 \\
\hline
\end{tabular}



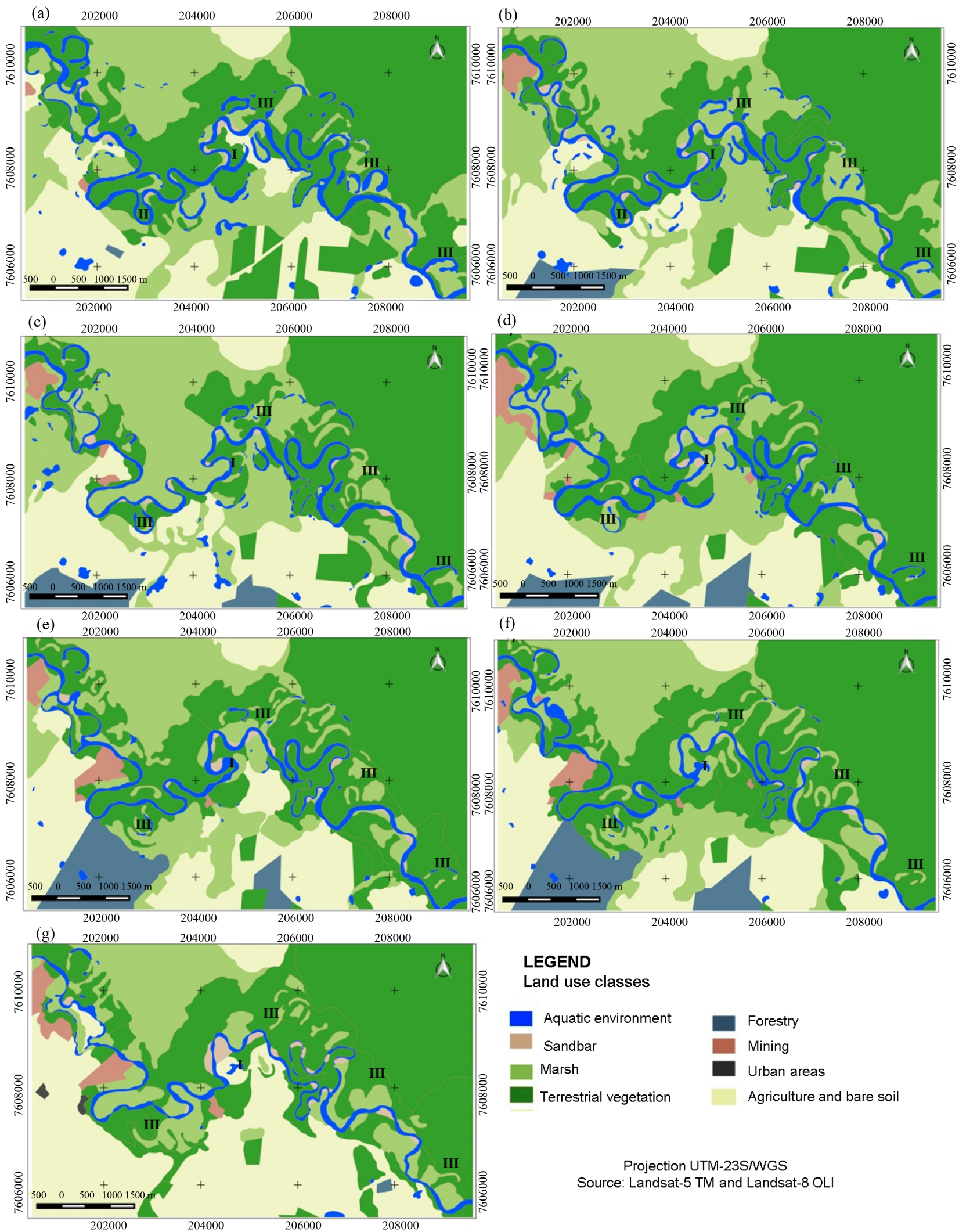

\section{LEGEND}

Land use classes

Aquatic environment $\quad$ Forestry

Sandbar Mining

Marsh $\square$ Urban areas

Terrestrial vegetation $\quad$ Agriculture and bare soil

Projection UTM-23SMGS

Source: Landsat-5 TM and Landsat- $8 \mathrm{OLI}$

Figure 2. Spatial configuration of land use/cover in Mogi Guaçu wetland (Southern Brazil), over the 30-year period: (a) 1984; (b) 1989; (c) 1994; (d) 1999; (e) 2004; (f) 2009 and (g) 2014. (I) Changes in the river course; (II) Genesis of a new oxbow lake; (III) Extinction of oxbow lakes connected and unconnected to the river channel. 
values $(R>0.78)$ emphasize a continuous replacement of terrestrial vegetation, with Cin lower than Cout during 1984-1989 ( $\mathrm{Cin}=0.19$, Cout $=0.36$ ), 1989-1994 $(\mathrm{Cin}=0.26$, Cout $=0.36)$, and 2009-2014 $(\mathrm{Cin}=0.29$, Cout $=0.36)$. Likewise, Cin is higher than the Cout during 1994-1999 $(\mathrm{Cin}=0.36$, Cout $=$ $0.20), 1999-2004(\mathrm{Cin}=0.28$, Cout $=0.18)$ and 2004-2009 $(\mathrm{Cin}=0.38$, Cout $=$ 0.32) (Table 2). Terrestrial vegetation changes include: (a) marsh/herbaceous vegetation conversion out for all period, (b) conversion out from 1984 to 1989, probably, related to the increase of agricultural land cover, and (c) a resulting gain from reforestation in anthropogenic land use.

The marsh//herbaceous was a dynamic land cover occupying around $18.0 \%$ $30.0 \%$ of the total study area (Table 1$)$, with high Retention Rate $(\mathrm{R})$ values $(0.5$ to 0.8 ), (Table 2), over the 30 -year period. Marshy plants living in the littoral zone of lakes and rivers are found in a fringe not exceeding a depth of $2 \mathrm{~m}$, since at least part of their leaves and inflorescences must remain emergent [18]. In the succession process, the marshland occupies the sandbar which is replaced by terrestrial vegetation. This condition was supported by the Cin or Cout values ranging from 0.02 to 0.42 , over the 30 -year period (Table 2).

Although low retention rate values $(\mathrm{R}<0.32)$ was observed for sandbars (Table 2), this land cover occupied less than $1 \%$ of the study area, between 1984 and 2014 (Table 1, and Figure 2). Primarily, sandbar land cover encompasses removal, transport and deposition of sediment throughout the drainage basin [35], and is subject to continuous change. These attributes support lower sandbar $\mathrm{R}(\mathrm{R}<0.20)$ values, after 1999 (Table 2). Since 2000, the Mogi-Gualu river flow rate values and flood pulse magnitude have not been enough to cover the total wetland area [11]. The sandbar land cover area converted to terrestrial vegetation and aquatic land use/cover (Figure 2) and these conversions promoted changes in the river sedimentation dynamics, which were further intensified by human activities.

The aquatic land use (river channel and oxbow lakes) and others natural land cover (marsh) have gradually decreased (Table 1), with genesis (II) and extinction (III) of oxbow lakes, and changes in the Mogi Guaçu river course (Figures $2(\mathrm{a})-(\mathrm{g}))$, although the predominance of natural land use, mainly represented by terrestrial vegetation land cover keeps the naturalness of the Mogi Guaçu wetland, over the 30 years (1984-2014),

The trajectory of oxbow lake and river land cover areas are a result of a continuous change in the temporal variability of the river channel (i.e. changes in the river course, genesis (II), and extinction (III) of oxbow lakes) (Figures 2(a)-(g)). All these changes in the Mogi Guaçu wetland are quite fast due to intensive erosion and sedimentation resulting from human and urban occupation, development of new mining areas, and vegetation removal for sugarcane cultivation increasing [11].

The $\mathrm{C}_{\mathrm{in}}$ and $\mathrm{C}_{\text {out }}$ rate values highlight the impact of land use/cover changes based on the conversion between a specific land use to another type which are highly dependent on the percentages of areas occupied in the wetland. Oxbow 
lakes, sandbars and river channel land cover occupied around 4.79\% - 7.91\% of total wetland area, with lower $\mathrm{C}_{\text {in }}$ and $\mathrm{C}_{\text {out }}$ rate values than other types of land use/cover, over the 30-year period (Table 2).

The low Retention Rate $(\mathrm{R}<0.50)$ values (Table 2$)$ and the decrease in occupied area of oxbow lakes land cover (Table 1), over the 30-year period, support the dynamic process of development, genesis, and extinction of this specific habitat. $C_{\text {out }}$ is higher than $C_{\text {in }}$, rate value, except during 1986-1994. However, the $\mathrm{C}_{\text {in }}$ and $\mathrm{C}_{\text {out }}$ values are smaller than $<0.08$ ) (Table 2). The $\mathrm{R}$ values for oxbow lakes land cover show high conversion rate to other land use/cover, particularly, between 2009 and 2014 ( $\mathrm{R}$ value of 0.01 or changes in 99\% of the oxbow lake area) (Table 2).

However, a decrease in the area of river channel land cover was observed more clearly from 2009 to 2014 , corresponding to a minimum $\mathrm{R}$ value (0.18), with $C_{\text {in }}(0.08)$ lower than $C_{\text {ou }}$ t value (0.13) (Table 2), probably, due to the reduction values of Mogi-Guaçu river flow rates, flood pulse, and days with rainfall. The changes in spatial heterogeneity of land use/cover design a Mogi-Guaçu wetland scenario showing a prolonged dry season, similar to what happened from 2013 to 2014, when an irregularity of rainfall during the rainy season was observed, resulting in river floodplain heterogeneity and complexity [11].

These processes have occurred naturally in the wetlands over centuries as a result of climate conditions and flood attributes that explain flood pulse magnitudes and flow rates, particularly, influenced by rainfall irregularity in the rainy season. However they can be accelerated by intensive agriculture activity similar to that observed for the Mogi Guaçu floodplain river [11]. Anthropogenic land use/cover (agriculture and exposure soil, urban area and mining) increase (2108\%, in 1984 to $33.43 \%$ in 2014) (Table 1 and Figure 2) can be considered as the main direct driver on naturalness change of the Mogi Guaçu wetland. This land use also showed the highest retention area ( $\mathrm{R}$ values), over the 30-year period, (above 75\%, except mining class) (Table 2).

The anthropogenic land use/cover intensification threatens biodiversity by reducing the $\alpha$-diversity of many taxa, particularly due oxbow lake extinction, over the 30 years period. Similarly, $\beta$-diversity between oxbow lake and marsh land cover may decrease due to loss of these habitats through terrestrial vegetation retention rates, over the 30-year period (Table 2).

Terrestrial vegetation and agriculture and bare soil land use/cover showed high $\mathrm{R}$ values, ranging from 0.71 to 1.00 (Table 2), have evidenced minimal quantitative changes, over the 30 -year period, since these land cover occupied together more than $65 \%$ of the total wetland area.

Furthermore, agriculture and bare soil showed high $\mathrm{R}$ values, ranging from 0.71 to 0.94 , characterized by prevalence and minimal changes for this land cover. The $C_{\text {in }}$ and $C_{\text {out }}$ rate values did not change from 1984 to 1994, corroborating this condition. The agriculture and bare soil land cover changes are highlighted from 1994 to 2009, when $C_{\text {in }}$ was lower than the $C_{\text {out }}$ rate values, except for the period from 2009 to 2014 when $C_{\text {in }}$ was higher than the $C_{\text {out }}$ value (Table 2). 
Urban and mining land cover have lower differences of $\mathrm{C}_{\text {in }}$ and $\mathrm{C}_{\text {out }}$ rate values (Table 2), over the 30-year period, showing an increase in occupied area, particularly after 1999. Urban and mining areas are characterized by intense changes in wetland, which ecological disturbance shows a high level of disruption. For example, urbanization alters the hydrologic flow regime of rivers by increasing surface cover impermeability. In turn, changes in the hydrologic regime can have significant implications for intended water used in river basins to maintain a balance between demand and water supply [36].

Over the 30-year period, the main land use trajectories in the Mogi Guaçu wetland was anthropogenic occupation. Sugarcane cultivation, development of new mining areas and sand removal, riparian forest removal, overfishing, alcohol distilleries, as well as pulp and paper plants are the main pressure drivers on wetland biodiversity.

The transformation of natural vegetation into cropland and urban area is an increasingly recognized threat to many South American wetlands, being of particular interest because wetlands affected by these activities leave out capacity to provide ecosystem services [9]. This condition was reported in the Mogi Guaçu river basin, where the sugarcane cultivation corresponds to the predominant anthropogenic land use [37]. These land use increased hydrological and physiographic changes throughout the Mogi Guaçu wetland, resulting in intensive erosion and sedimentation along the river channel [11].

The new Brazilian "Forest Code" has contributed to the agricultural expansion in wetlands, because the permanent protection zone of wetlands has been significantly reduced [9].

The Secretary of State for the Environment (São Paulo, Brazil) defined the Area Under Special Protection of Jataí (ASPE Jatai), by Resolution No. 92, September 21, 2013, due the anthropogenic pressure exerted on the all Mogi Gaçu River basin, and the importance of conservation of the most representative forest remnants, Luís Antônio Experimental Station and Jataí Ecological Station. The ASPE Jataí, with approximately 22,494 ha (Figure 3), is intended, protection of terrestrial and wetland ecosystems, as well as their respective fauna and flora, applying to it the rules and measures defined by the terms of the legislation in force. These legal strategies comply with the needs to facilitate the integration of planning and monitoring of biodiversity in areas of outstanding environmental value, like wetlands, aiming to implement protected areas under the terms of Federal Law 9985 of July 18, 2000.

Therefore, implementing ecological and economic zoning on the Mogi Guaçu River basin is necessary to ensure the protection and conservation of water resources and ecological life-support systems, particularly in the surrounding municipalities. These zoning would require the maintenance of land use standards based on biotic, geological, agricultural, extractive and cultural characteristics, among others, and aim to improve the well-being of the local population. Environmental zoning throughout the Mogi Guaçu River basin can be subsidized and supported by Environmental Secretary Resolution No. 92/2013, which de 


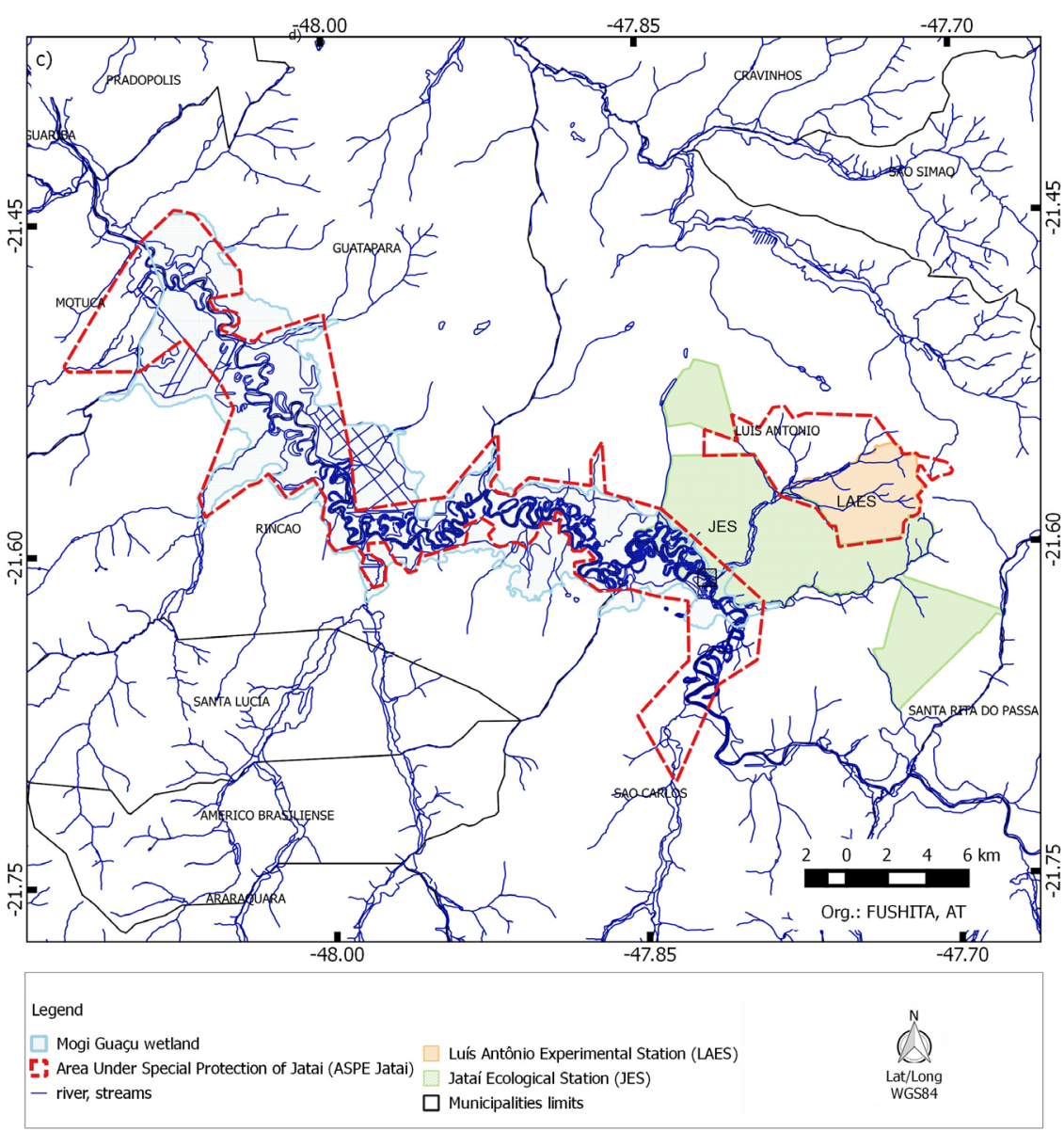

Figure 3. Location of the Area Under Special Protection of Jataí (ASPE Jataí) and Mogi Guaçu wetland (Southern, Brazil). In detail: the Jatai Ecological Station (JES), Luis Antônio Experimental Station (LAES), study area, and surrounding municipalities.

fines the ASPE Jatai because of local anthropogenic pressures, influencing in availability and quality of water resources and representative forest remnants, and balance socio-economic development with environmental conservation.

Specific regulations are essential for the ecological integrity maintenance for wetland management. Moreover, monitoring has become the focus of the Ramsar Convention [9] [38]. The primary focus for management purposes is therefore to provide a reference in which wetland can still return to natural conditions. However, the information about the level of natural condition and the changes in land use trajectory, as well as the dynamics of the wetlands are little known and very restricted to the current years. The main attention for purpose management is thus often a reference when the wetland is perceived to the return of initial natural condition [39].

\section{Conclusions}

Although rainfall is highly correlated with flow rates values, groundwater availability and land use changes are mainly driving forces that can affect hydrological periodicity of the river flow intensity and flood pulse magnitude. Higher values 
of all flood attributes were observed from 1980 to 1984, when the very strong warm El Niño Southern Oscillation phase occurred.

The main land use change occurred from 1994 to 1999 and 2009 to 2014. It was related to higher total landscape conversion rate values, and consequently, lower retention rate values for oxbow lakes, sandbars and rivers. The habitat diversity in wetland (oxbow lakes, sandbars and rivers) declined, while terrestrial vegetation and agricultural land cover increased, and these overall mosaics became more continuous and homogenous.

As terrestrial vegetation and agricultural expansion show an increase tendency scenario, over the 30-year period, the remaining natural habitats, as oxbow lakes, sandbars and marsh, have been modified to accommodate anthropogenic land cover. The extension, connectivity and shape complexity of Mogi Guaçu wetland result from the transition in land use/cover from natural to anthropogenic landscape. It means that wetland extension was dependent of their land use context, over the 30 years (1984-2014).

In the events of continuity of prolonged drought period, the irregularity of the hydrological period influencing the level of river flow, and the occurrence of periodic flooding pulses, we conclude the paper by considering the land use/cover trajectory, over the 30-year period, as the main driver for Mogi-Guaçu wetland to undergoing a quick transition from natural to cultural landscape. A more precise scenario points that Mogi-Guaçu wetland is currently threatened by a land use unsustainable trend related to a quick anthropic occupation of the floodplain river, resulting in loss of habitat, biodiversity and ecosystem services due to land use changes and its impact on the structure and function of wetlands. These changes are promoting unstable conditions within the Mogi Guaçu floodplain river and may soon approach a climax, beyond which the natural wetland ecosystem will be unable to sustain them.

These results make it possible for policy makers, scientists and stakeholders to identify at a glance the land uses which are hindered or enhanced under various scenarios of land use change, over the 30-year period, and makes it possible to explore the trade-offs between them to improve wetland management. This first effort to develop and apply rate values of land use conversion on land use/cover trajectory in a wetland ecosystem may find this methodology useful for monitoring and management others ecosystems with similar vulnerabilities and conservation issues.

\section{References}

[1] Burgin, S., Franklin, M.J.M. and Hull, L. (2016) Wetlands Loss in the Transition to Urbanization: A Case Study from Western Sydney, Australia. Wetlands, 36, 985-994. https://doi.org/10.1007/s13157-016-0813-0

[2] Millennium Ecosystem Assessment (2005) Ecosystems and Human Well-Being: Biodiversity Synthesis. World Resources Institute, Washington DC.

[3] Gardner, R.C., et al. (2015) State of the World's Wetlands and Their Services to People: A Compilation of Recent Analyses. Ramsar Briefing Note 7, Ramsar.

[4] Cui, L., et al. (2015) Integrated Approach Based on a Regional Habitat Succession 
Model to Assess Wetland Landscape Ecological Degradation. Wetlands, 35, 281-289. https://doi.org/10.1007/s13157-014-0617-z

[5] Fischer, J., et al. (2015) Influence of Riparian and Watershed Alterations on Sandbars in a Great Plains River. River Research and Applications, 31, 1140-1150. https://doi.org/10.1002/rra.2811

[6] He, X., et al. (2015) Natural and Anthropogenic Causes of Vegetation Changes in Riparian Wetlands along the Lower Reaches of the Yellow River, China. Wetlands, 35, 391-399. https://doi.org/10.1007/s13157-015-0628-4

[7] Narumalani, S., Mishra, D.R. and Rothwell, R.G. (2004) Change Detection and Landscape Metrics for Inferring Anthropogenic Processes in the Greater EFMO Area. Remote Sensing of Environment, 91, 478-489.

https://doi.org/10.1016/j.rse.2004.04.008

[8] Gossner, M.M., et al. (2016) Land-Use Intensification Cause Multitrophic Homogenization of Grassland Communities. Nature, 540, 266-269. https://doi.org/10.1038/nature20575

[9] Wittmann, F., et al. (2015) Implementation of the Ramsar Convention on South American Wetlands: An Update. Research and Reports in Biodiversity Studies, 4, 47-58. https://doi.org/10.2147/RRBS.S64502

[10] Kiedrzyński, M., et al. (2014) Historical Land Use, Actual Vegetation, and the Hemeroby Levels in Ecological Evaluation of an Urban River Valley in Perspective of Its Rehabilitation Plan. Polish Journal of Environmental Studies, 23, 109-117.

[11] Fushita, A.T. and Santos, J.E. (2015) Landscape Heterogeneity and Complexity in River Wetland Ecosystems. Sky Journal of Soil Science and Environmental Management, 4, 079-086.

[12] Santos, J.E. and Mozeto, A.A. (1992) Program of Analysis of Ecosystems and Environmental Monitoring: Ecological Station of Jataí (Luiz Antônio, SP). Ecology of Wetlands of the Floodplain of the Mogi Guaçu River-Jataí Project, PPGERN, São Carlos/UFSCar.

[13] CBH-Mogi (2008) Mogi Guaçu Watershed Committee: Status Report: 2008-2011.

[14] DAEE (2016) Fluviometric Database of the State of São Paulo. http://www.sigrh.sp.gov.br/

[15] INMET (2016) Meteorological Database for Teaching and Research. http://www.inmet.gov.br/portal/index.php?r=bdmep/bdmep

[16] Oksanen, F.J., et al. (2017) Vegan: Community Ecology Package. R package Version 2.4-3. https://CRAN.R-project.org/package=vegan

[17] R Core Team (2017) R: A Language and Environment for Statistical Computing. R Foundation for Statistical Computing, Vienna. https://www.R-project.org/

[18] Neiff, J.J. and Poi de Neiff, A. (2003) Connectivity Processes as a Basis for Management of Aquatic Plants. In: Thomaz, S.M. and Bini, M., Eds., Ecology and Management of Aquatic Macrophytes, Maringá, Brazil, 39-58.

[19] Stevaux, J.C., et al. (2013) Connectivity Processes and Riparian Vegetation of the Upper Paraná River, Brazil. Journal of South American Earth Sciences, 46, 113-121. https://doi.org/10.1016/j.jsames.2011.12.007

[20] Congalton, R.G. (1991) A Review of Assessing the Accuracy of Classifications of Remotely Sensed Data. Remote Sensing of Environment, 37, 35-46. https://doi.org/10.1016/0034-4257(91)90048-B

[21] Hijmans, R.J. (2015) Raster: Geographic Data Analysis and Modeling. R Package Version 2.5-2. http://CRAN.R-project.org/package=raster 
[22] Hijmans, R.J., et al. (2015) Dismo: Species Distribution Modeling. R Package Version 1.0-12. http://CRAN.R-project.org/package=dismo

[23] Xue, C., et al. (2015) Evolution of a Multidimensional Architectural Landscape under Urban Regeneration: A Case Study of Jinan, China. Ecological Indicators, 55, 12-22. https://doi.org/10.1016/j.ecolind.2015.02.036

[24] Ballester, M.V.R. and Santos, J.E. (2001) Biogenic Gases $\left(\mathrm{CH}_{4}, \mathrm{CO}_{2}\right.$ and $\left.\mathrm{O}_{2}\right)$ Distribution in a Riverine Wetland System. Oecologia Brasiliensis, 9, 21-31. https://doi.org/10.4257/oeco.2001.0901.03

[25] Schöngart, J. and Junk, W.J. (2007) Forecasting the Flood-Pulse in Central Amazonia by ENSO-Indices. Journal of Hydrology, 335, 124-132. https://doi.org/10.1016/j.jhydrol.2006.11.005

[26] Ward, P.J., et al. (2016) Flood Frequencies and Durations and Their Response to El Niño Southern Oscillation: Global Analysis. Journal of Hydrology, 539, 358-378. https://doi.org/10.1016/j.jhydrol.2016.05.045

[27] Barros, V.R., Grimm, A.M. and Doyle, M.E. (2002) Relationship between Temperature and Circulation in Southeastern South America and its Influence from El Niño and La Niña Events. Journal of the Meteorological Society of Japan, 80, 21-32. https://doi.org/10.2151/jmsj.80.21

[28] Chechi, L. and Sanches, F.O. (2013) The Use of the Rain Anomaly Index (IAC) in the evaluation of the El Niño Southern Oscillation (ENSO) Phenomenon in the Upper Uruguay Gaúcho between 1957-2012. Brazilian Journal of Physical Geography, 6, 1586-1597.

[29] CPTEC (2016) Occurrence of El Niño. http://enos.cptec.inpe.br/

[30] Grimm, A.M. (2003) The El Niño Impact on the Summer Monsoon in Brazil: Regional Processes versus Remote Influences. Journal of Climate, 16, 263-280. https://doi.org/10.1175/1520-0442(2003)016<0263:TENIOT >2.0.CO;2

[31] National Weather Service Organization (2016) El Niño and La Niña Years and Intensities Based on Oceanic Niño Index (ONI). http://www.cpc.noaa.gov/

[32] Bullock, A. and Acreman, M. (2003) The Role of Wetlands in the Hydrological Cycle. Hydrology and Earth System Sciences, 7, 358-389. https://doi.org/10.5194/hess-7-358-2003

[33] Famiglietti, J.S. (2014) The Global Groundwater Crisis. Nature Climate Change, 4, 945-948. https://doi.org/10.1038/nclimate2425

[34] McGregor, S., et al. (2013) Inferred Changes in El Niño-Southern Oscillation Variance over the Past Six Centuries. Climate of the Past, 9, 2269-2284.

https://doi.org/10.5194/cp-9-2269-2013

[35] Christofoletti, A. (1981) River Geomorphology. Edgar Blucher Ltda, São Paulo.

[36] Wu, F., et al. (2015) Present and Future of Urban Water Balance in the Rapidly Urbanizing Heihe River Basin, Northwest China. Ecological Modelling, 318, 254-264. https://doi.org/10.1016/j.ecolmodel.2014.11.032

[37] Romanini, E., et al. (2016) An Approach to Environmental Planning and Sustainable Management of Watersheds and Municipalities in Southeastern Brazil. Open Journal of Ecology, 6, 667-685. https://doi.org/10.4236/oje.2016.611062

[38] McInnes, R.J., et al. (2017) Wetland Ecosystem Services and the Ramsar Convention: an Assessment of Needs. Wetlands, 37, 123-134. https://doi.org/10.1007/s13157-016-0849-1

[39] Davidson, N.C. (2014) How Much Wetland Has the World Lost? Long-Term and Recent Trends in Global Wetland Area. Marine and Freshwater Research, 65, 934-941. https://doi.org/10.1071/MF14173 